\title{
ESTIMATING MAIZE EAR GRAIN YIELDS ON FARM
}

\author{
M. M. Elsahookie ${ }^{1}$ \\ S. H. Cheyed \\ Prof. \\ A. A. Dawood \\ Prof. Emeritus \\ Researcher \\ 'College of Agriculture Engineering Science, University of Baghdad. \\ Ministry of Agriculture office of Agriculture Research. \\ elsahookie.emeritus@yahoo.com
}

\section{ABSTRACT}

Crop growth modelling is one of the important sciences in field crop sciences for it helps to reduce time and effort in searching for a fact or result. This article was dealed with a formula to predict maize ear grain weight when plants still standing on farm. Two genotypes of maize were used in this trial, a hybrid of feed maize was used in 2018 and an open-pollinated cultivar of pop corn in 2019. Ear length and diameter were measured on 50 randomly taken plants of full seed - set before harvest .Ears were harvested later, air dried ,threshed and weighed, then yield adjusted to 15\% moisture .Ears were considered as cylinder , and volumes of each ear were calculated .Date of observed ear grain weights and their volumes were analyzed for their correlation and regression, they were fit in both years .The expected ear grain weight in 2018 formula was: expected dry ear grain weight $(\mathrm{g})=-\mathbf{0 . 1 3 4 2}+\mathbf{0 . 4 8 7 1}$ ear volume $\left(\mathrm{cm}^{3}\right)$ and in 2019 , the formula was : expected dry ear grain weight $(\mathrm{g})=+0.3509+0.4776$ ear volume $\left(\mathrm{cm}^{3}\right)$. Date of observed and expected dry ear grain weights was analyzed by $\mathrm{t}$ - test. The results showed high similarity between observed and expected ear weights, indicating that these two equations will be helpful to estimate dry ear grain weight of maize, while plants still on farm.

*Key words: Zea mays L., everta, ear dimensions, relative constant.

الساهوكي وآخرون

مجلة العلوم الزراعية العراقية -1224-1219:52: 521021 (5)

$$
\begin{aligned}
& \text { تقدير حاصل حبوب عزنوص الذرة الصفراء حقلياً }
\end{aligned}
$$

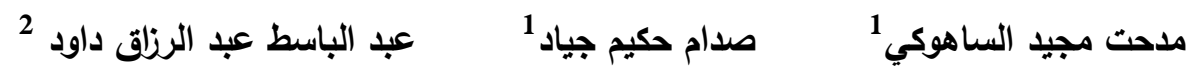

$$
\begin{aligned}
& 1 \text { قسم المحاصيل الحقلية-كلية علوم الهندسة الزراعية - جامعة بغداد. } 2 \text { دائرة البحوث الزراعية - وزارة الزراعة العراقية } \\
& \text { المستخلص: }
\end{aligned}
$$

تعد نمذجة نمو المحصول احد العلوم الهامة في علوم المحاصيل الحقلية لاختزال الزمن والجهذ في البحث عن نتيجة محددة. كان هدف هذا البحث وضع معادلة يمكن بواسطتها تقدير حاصل حبوب عرنوص الذرة الصفراء في الحقل بغض النظر عن

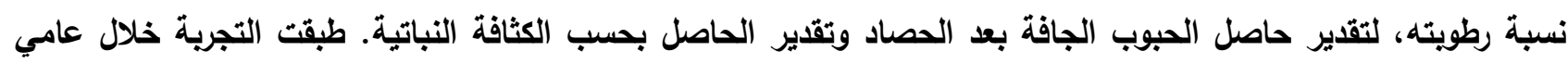
2018 و 2019 في الموسم الخريفي. استخدم في العام الأول هجين ذرة صفراء علفية( Zm21×Zm60) وفي العام الثاني صنف محسن من الذرة الفشار (الشامية). أخذت قبل الحصاد خمسون عرنوصاً وقيست إبعادها على إنها اسطوانية ويعد نزع

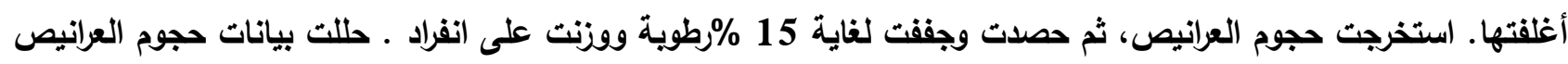

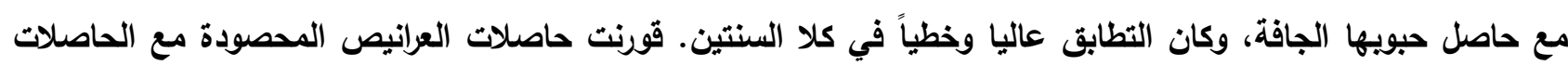
المقدرة بالمعادلة بتحليل(t) كما ربطت البيانات للحاصل المتوقع في السنة الأولى وعلاقتها بالحجم بالمعادلة التالية: (غم) حاصل الحبوب المتوقع الجاف للعرنوص = - 0.1342 + 0.4871 حجم العرنوص (سم²). وللسنة الثانية: (غم) حاصل

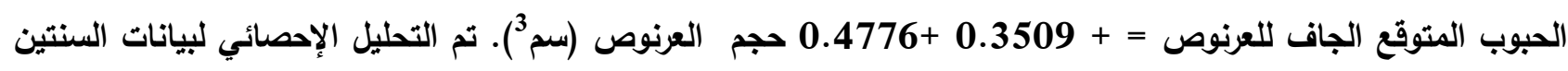
واثبت (ختبار(t) عدم معنوية الفرق بين الحاصل المتوقع والحاصل الفعلي على مستوى احتمال 82 \% للسنة الأولى و 85 \%

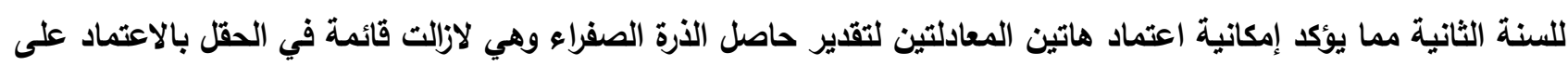
حجم العزنوص على انه اسطوانة.

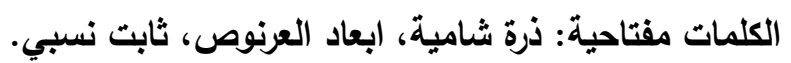




\section{INTRODUCTION}

Crop growth modelling is a very helpful science to understand and / or estimate some parameters in crop growth and yield. Hardan and Elsahookie (7) worked on estimating leaf area of sunflowers (Helianthus annus L.) by measuring dimensions of some plant leaves, and capitulum diameter to estimate plant seed yield. Previous results were also found by measuring sunflower diameter to estimate plant seed yield, for the highly significant correlation between sunflower capitulum area and seed yield $(4,8,12,13,16,19)$. On the other hand, Elsahookie and Eltaweel (8) and Elsahookie et al. (7) have found similar result on the significant and positive correlation between sunflower capitulum and its corresponding seed yield. Turner and Rawson (19) and Vranceanu et al. (20) worked on other indices on sunflower. Meanwhile, Alfalahi and Elsahookie (1) found significant correlation and regression between chickpea (Cicer arietinum) plant seed yield and some other plant traits and concluded that number of pods and branches per plant were the most correlated to plant seed yield. This result was in full agreement with that obtained by AlNuaimi and Elsahookie (3) on soybean (Glycine max L. Merrill ), and Singh et al. (18) on rice (Oryza sativa L.). Some recent researchers worked on maize, Al-Khafajy et al. (2) estimated grain yield of $F_{2}$ plants of hybrids by using a formula depending on parental yield averages and $F_{1}$ grain yield average, without a need to grow $\mathrm{F}_{2}$ seeds. On maize too, Cheyed and Elsahookie (5) worked on percent of seedling emergence and correlated that with predicted grain yield. Scharf and Lory (17) used aerial photographs to calibrate maize leaf color without direct measurement in the field to tell how much nitrogen the crop needs. This method was also used on some grasses for same purpose (14). Meanwhile, Nielson (15) predicted maize grain yield by number of rows / ear, and number of kernels / row before the crop matured. More recently, Elsahookie et al. (11) predicted maize grain yield of 25 genotypes counting on ear dimensions. On sorghum (Sorghum bicolor L. Moench), Elsahookie and Cheyed (10) estimated total plant leaf area of sorghum by measuring one leaf length. Similar result was found on maize by same researchers (9). The objective of this article was to estimate ear grain yield of a maize (Zea mays L.) hybrid and of an open- pollinated cultivar of pop corn while plants still on farm before harvest by using ear dimensions considered as a cylinder. This was an early estimate of ear grain weight before harvest, and by multiplying with planting population density we will get productivity of the crop.

\section{MATERIALS AND METHODS}

Two experiments were undertaken on the $\mathrm{x}$ farm of the Coll. of Agric. Eng. Sci., Univ. of Baghdad in 2018 and 2019. In the fall of each year an area was prepared by ploughing and disking, then divided into $3 \times 3 \mathrm{~m}$ plots, in 2018, $F_{1}$ seeds of hybrid maize ( $\mathrm{Zm} 60$ $\times \mathrm{Zm} 21$ ) was grown in mid -July, while in the second year (2019), an open - pollinated local cultivar of popcorn (Zea mays everta) was used. Planting was in rows of $50 \times 25 \mathrm{~cm}$. All management practices were done as needed. At time of physiologic maturity, 50 ears of full seed - set were labeled, and husk removed, then length and diameter of ears were measured at the middle of ear. Lengths were measured by a ruler, while diameter measured by a vernier. At time of harvest, all ears were collected, air dried, threshed, weighed, and grain yields adjusted to $15 \%$ moisture (6). Volumes of all ears were determined as a cylinder. The mean of observed ear grain weight was divided by mean of ear volume to determine a constant. Two constants were calculated in each season, then volumes of ears of each genotype were multiplied by the constant to predict ear grain weights. The expected ear grain weights were tested for correlation and regression (Fig .1 and 2). Both were linearly fit $(r=1.0)$. 


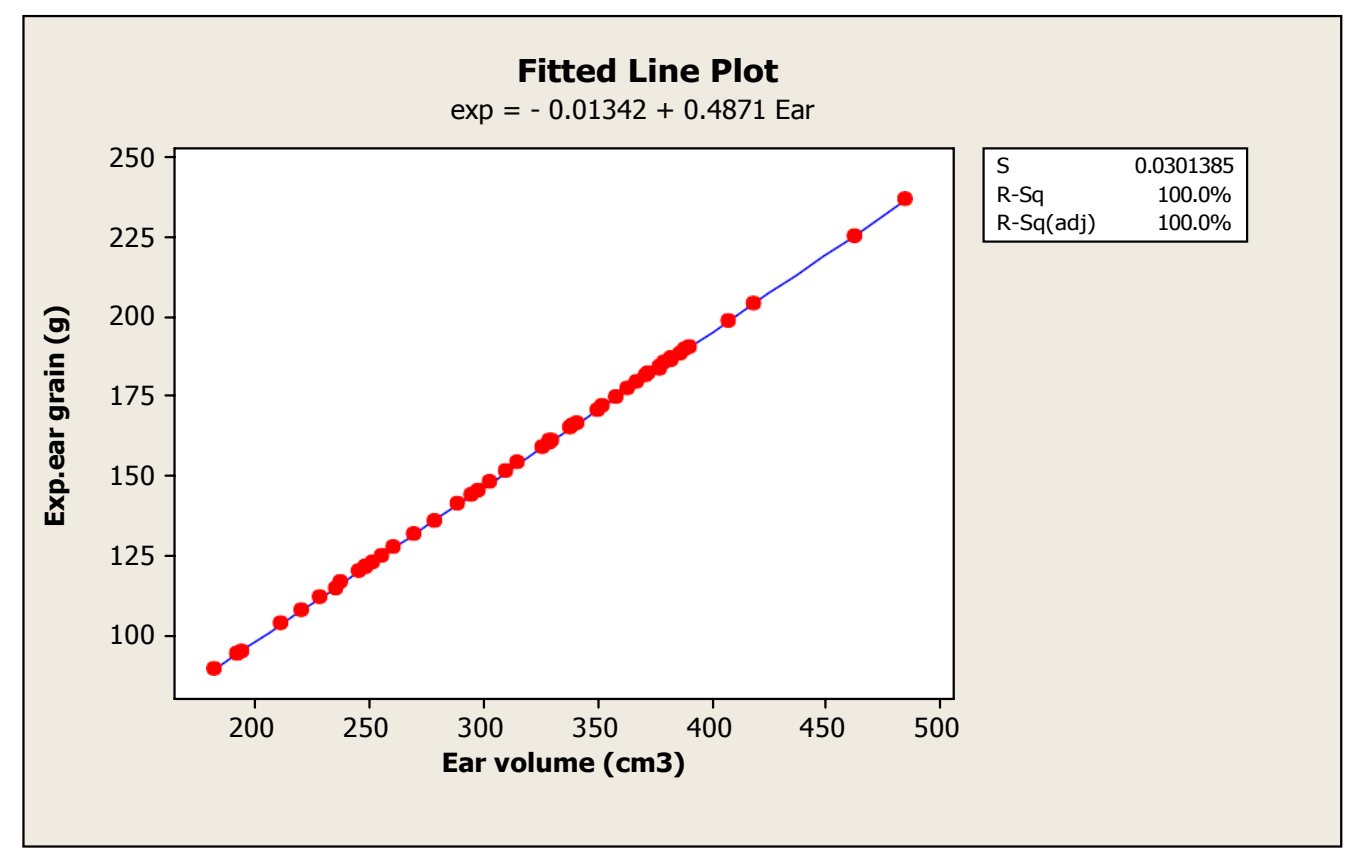

Fig.1.Correlation plot and regression equation for expected ear grain yields and their volumes for the hybrid $\mathrm{Zm60} \times \mathrm{Zm} 21$

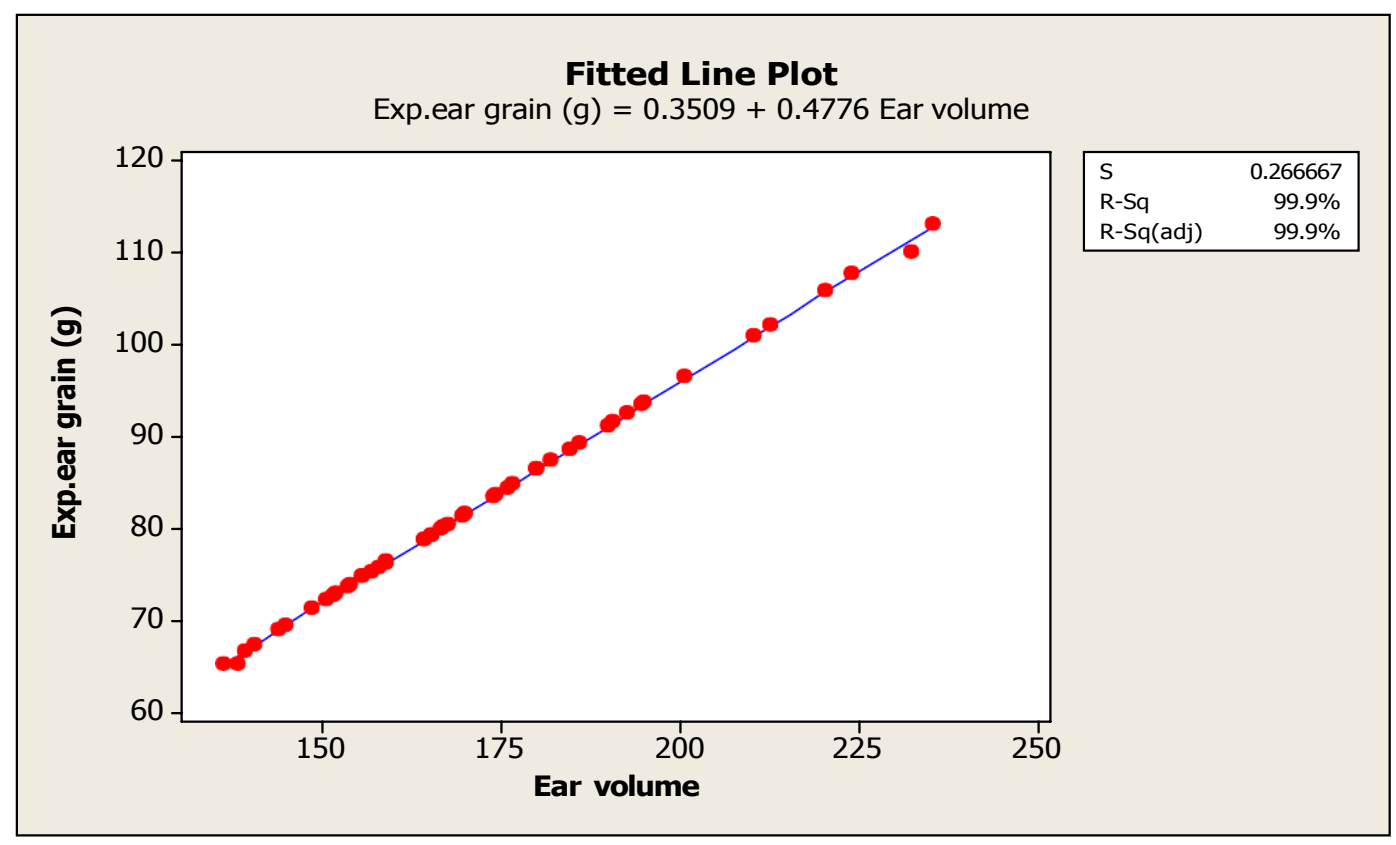

Fig.2.Correlation plot and regression equation for expected ear grain yields and their volumes for the popcorn cultivar

\section{RESULTS AND DISCUSSION}

The constant value was obtained by dividing the mean of observed ear grain weight by the mean of ear volumes of the 50 ears sample of each genotype. The expected ear grain weights were calculated by multiplying each ear volume by the corresponding constant. The constant for the hybrid $\mathrm{Zm} 60 \times \mathrm{Zm} 21$ was 0.487 and for the popcorn cultivar was 0.480.Results of expected ear grain weights were tested for correlation and regression with their corresponding volumes. The correlation in both years were highly significant and positive (Fig. 1 and 2). The regression equation to determine expected ear grain weight in the first year for maize hybrid $\mathrm{Zm60 \times Zm} 21$ was: expected ear grain weight $(\mathrm{g})=$ $0.01342+0.4871$ ear volume $\left(\mathrm{cm}^{3}\right)$ and for the popcorn cultivar was: 
expected ear grain weight $(\mathrm{g})=+0.3509$ +0.4776 ear volume $\left(\mathrm{cm}^{3}\right)$.

Values of expected ear grain weights were adjusted to $15 \%$ moisture in our calculations. The two genotypes were planted in $50 \times 25 \mathrm{~cm}$ rows. When we multiply population density by ear dry grain weight (153.2 g) (Table 1) will have productivity of $12.25 \mathrm{t} /$ ha for maize hybrid Zm60×Zm 21. By the same method, we will have a productivity of popcorn cultivar by multiplying ear grain yield (83.0g) (Table 2) by population density, the expected will be $6.64 \mathrm{t} / \mathrm{ha}$. The constant used here for feed maize was 0.487 while it was found to be 0.30 in a previous study (11). This could be attributed to that we used here just one genotype, while in that study they used 25 genotypes.

Table 1. Grain yields of maize hybrid $(\mathrm{Zm60} \times \mathrm{Zm} 21)$, observed values and predicted by formula in 2018 .

\begin{tabular}{|c|c|c|c|c|c|c|c|}
\hline $\mathbf{N}$ & $\begin{array}{c}\text { Ear } \\
\text { volume } \\
\mathrm{Cm}^{3}\end{array}$ & $\begin{array}{l}\text { Obs. Ear } \\
\text { grain (g) }\end{array}$ & $\begin{array}{l}\text { Exp.ear } \\
\text { grain }(g)\end{array}$ & $\mathbf{N}$ & $\begin{array}{c}\text { Ear volume } \\
\mathrm{Cm}^{3}\end{array}$ & $\begin{array}{l}\text { Obs. Ear } \\
\text { grain (g) }\end{array}$ & $\begin{array}{c}\text { Exp.ear } \\
\text { grain }(g)\end{array}$ \\
\hline 1 & 390.2 & 183.0 & 190.0 & 26 & 462.4 & 203.8 & 225.2 \\
\hline 2 & 350.3 & 170.6 & 170.6 & 27 & 278.7 & 154.1 & 135.7 \\
\hline 3 & 249.2 & 103.0 & 121.4 & 28 & 377.0 & 188.9 & 183.6 \\
\hline 4 & 256.2 & 137.7 & 124.8 & 29 & 326.0 & 176.6 & 158.8 \\
\hline 5 & 388.8 & 184.4 & 189.3 & 30 & 192.7 & 102.6 & 93.8 \\
\hline 6 & 382.7 & 204.1 & 186.4 & 31 & 246.2 & 120.0 & 119.9 \\
\hline 7 & 315.6 & 136.6 & 153.7 & 32 & 182.7 & 90.8 & 89.0 \\
\hline 8 & 235.4 & 126.5 & 114.6 & 33 & 192.7 & 100.2 & 93.8 \\
\hline 9 & 339.3 & 169.6 & 165.2 & 34 & 329.8 & 155.9 & 160.6 \\
\hline 10 & 367.5 & 193.2 & 179.0 & 35 & 249.3 & 108.9 & 121.4 \\
\hline 11 & 261.3 & 118.8 & 127.3 & 36 & 238.2 & 113.3 & 116.0 \\
\hline 12 & 419.0 & 214.1 & 204.1 & 37 & 352.7 & 168.2 & 171.8 \\
\hline 13 & 341.0 & 165.0 & 166.1 & 38 & 194.7 & 98.8 & 94.8 \\
\hline 14 & 294.8 & 176.4 & 143.6 & 39 & 228.5 & 105.5 & 111.3 \\
\hline 15 & 338.1 & 152.7 & 164.7 & 40 & 371.5 & 168.3 & 180.9 \\
\hline 16 & 310.0 & 122.6 & 151.0 & 41 & 485.3 & 244.2 & 236.3 \\
\hline 17 & 329.5 & 159.3 & 160.5 & 42 & 303.5 & 137.6 & 147.8 \\
\hline 18 & 252.0 & 112.2 & 122.7 & 43 & 407.5 & 187.4 & 198.5 \\
\hline 19 & 382.1 & 186.6 & 186.1 & 44 & 220.4 & 114.1 & 107.3 \\
\hline 20 & 379.8 & 194.8 & 185.0 & 45 & 329.2 & 181.3 & 160.3 \\
\hline 21 & 358.1 & 160.3 & 174.4 & 46 & 363.1 & 195.9 & 176.8 \\
\hline 22 & 386.4 & 193.3 & 188.2 & 47 & 270.0 & 130.7 & 131.5 \\
\hline 23 & 372.9 & 213.7 & 181.6 & 48 & 249.3 & 124.4 & 121.4 \\
\hline 24 & 298.0 & 140.0 & 145.1 & 49 & 211.9 & 105.3 & 103.2 \\
\hline \multirow[t]{2}{*}{25} & 288.8 & 144.8 & 140.7 & 50 & 377.7 & 205.1 & 183.9 \\
\hline & & & & $\overline{\boldsymbol{X}}$ & & 153.1 & 153.2 \\
\hline
\end{tabular}

Observed ear grain yield

$\frac{\text { Mean } \pm \text { SD }}{154.9 \pm 38.1}$

It implies that for each genotype we have to have its own constant. However, predicted maize grain yield still beneficial by using the regression formula which was not determined in that study. However, the constants between feed maize and popcorn were different, and expected ear grain yield

$\underline{\text { Mean } \pm \text { SD }}$

$153.2 \pm 35.5$

also the regression equations, that was due to ear dimensions differences and kernel sizes. The popcorn kernel weighs $126 \mathrm{mg}$ while feed maize weighs $230 \mathrm{mg}$. Accordingly, shelling percent will be different, and ear grain weight will be different too. 
Table 2. Grain yields of pop corn ears, observed and predicted values by formula in 2019

\begin{tabular}{|c|c|c|c|c|c|c|c|}
\hline $\mathbf{N}$ & $\begin{array}{c}\text { Ear volume } \\
\mathbf{C m}^{3}\end{array}$ & $\begin{array}{l}\text { Obs. Ear } \\
\text { grain }(\mathrm{g})\end{array}$ & $\begin{array}{c}\text { Exp.ear } \\
\text { grain }(g)\end{array}$ & $\mathbf{N}$ & $\begin{array}{c}\text { Ear volume } \\
\mathbf{C m}^{3}\end{array}$ & $\begin{array}{l}\text { Obs. Ear } \\
\text { grain (g) }\end{array}$ & $\begin{array}{c}\text { Exp.ear } \\
\text { grain (g) }\end{array}$ \\
\hline 1 & 165.5 & 78.9 & 79.4 & 26 & 167.8 & 79.4 & 80.4 \\
\hline 2 & 166.6 & 76.5 & 80.0 & 27 & 232.6 & 80.0 & 11.7 \\
\hline 3 & 157.9 & 86.8 & 75.8 & 28 & 159.1 & 75.8 & 76.4 \\
\hline 4 & 169.9 & 75.8 & 81.6 & 29 & 156.9 & 81.6 & 75.3 \\
\hline 5 & 180.0 & 98.9 & 86.4 & 30 & 170.0 & 86.4 & 81.6 \\
\hline 6 & 192.7 & 94.1 & 92.5 & 31 & 176.0 & 92.5 & 84.5 \\
\hline 7 & 153.7 & 60.7 & 73.8 & 32 & 190.0 & 73.8 & 91.2 \\
\hline 8 & 200.8 & 96.6 & 96.4 & 33 & 140.7 & 96.4 & 67.5 \\
\hline 9 & 136.2 & 68.2 & 65.4 & 34 & 186.0 & 65.4 & 89.3 \\
\hline 10 & 153.9 & 74.8 & 73.9 & 35 & 213.0 & 73.9 & 102.2 \\
\hline 11 & 174.1 & 90.7 & 83.6 & 36 & 148.5 & 83.6 & 71.3 \\
\hline 12 & 164.4 & 82.8 & 78.9 & 37 & 195.2 & 78.9 & 93.7 \\
\hline 13 & 169.8 & 76.7 & 81.5 & 38 & 182.1 & 81.5 & 87.4 \\
\hline 14 & 184.8 & 79.0 & 88.7 & 39 & 180.0 & 88.7 & 86.4 \\
\hline 15 & 155.8 & 75.7 & 74.8 & 40 & 167.0 & 74.8 & 80.2 \\
\hline 16 & 165.5 & 66.9 & 79.4 & 41 & 159.0 & 79.4 & 76.3 \\
\hline 17 & 165.5 & 76.9 & 79.4 & 42 & 224.2 & 79.4 & 107.6 \\
\hline 18 & 164.4 & 84.9 & 78.9 & 43 & 235.5 & 78.9 & 113.0 \\
\hline 19 & 176.8 & 88.9 & 84.9 & 44 & 145.0 & 84.9 & 69.6 \\
\hline 20 & 190.9 & 82.5 & 91.6 & 45 & 144.0 & 91.6 & 69.1 \\
\hline 21 & 220.6 & 91.7 & 105.9 & 46 & 139.2 & 105.6 & 66.8 \\
\hline 22 & 151.9 & 82.9 & 72.9 & 47 & 210.5 & 72.9 & 101.0 \\
\hline 23 & 151.5 & 87.9 & 72.7 & 48 & 150.6 & 72.7 & 72.3 \\
\hline 24 & 174.3 & 98.3 & 83.7 & 49 & 138.3 & 83.7 & 65.4 \\
\hline \multirow[t]{2}{*}{25} & 194.7 & 96.5 & 93.4 & 50 & 155.8 & 93.4 & 74.8 \\
\hline & & & & $\overline{\boldsymbol{X}}$ & & 83.01 & 83.06 \\
\hline \multicolumn{4}{|c|}{ Observed ear grain yield } & \multicolumn{3}{|c|}{ expected ear grain yield } & t-test \\
\hline \multicolumn{3}{|c|}{ Mean $\pm \mathrm{SD}$} & & \multicolumn{3}{|c|}{ Mean \pm SD } & Mean \pm SD \\
\hline \multicolumn{4}{|c|}{$\overline{154.9 \pm 38.1}$} & & $\overline{153.2 \pm 35.5}$ & & $0.85 \mathrm{n} . \mathrm{s}$ \\
\hline
\end{tabular}

We can conclude from these results that the observed and expected ear grain weights for both genotypes were very close to each other counting on the insignificance of their means as shown by $\mathrm{t}$-test (Tables 1 and 2). This gives us a quick and non-distructive method to estimate maize grain yield while plants still standing on farm. The differences among genotypes in ear size and seed - set could give some deviation. So, each genotype should have its own constant for better grain yield prediction.

\section{REFERENCES}

1. Alfalalhi, M.A. and M.M. Elsahookie. 1996. Correlation and regression among traits of chickpea. The Iraqi J. Agric. Sci.27(1):107112

2. Al-Khafajy, M.J., M.M. Elsahookie, and S.H. Cheyed. 2012. A formula to predict inbreeding depression in F2 population of maize. The Iraqi J. Agric. Sci., 43(1):1-9

3. Al-Nuaimi, T.S. and M.M. Elashookie. 1993. Selection criterion of soybean. Ist. Conf. of Field Crops, Baghdad, Iraq, p.198- 213

4. Cantagallo, J.E., C.A. Chernenti and A.J. Hall. 1997. Number of seeds per unit area in sunflower correlates well with a photo thermal quotient. Crop Sci., 37:1780- 1789

5. Cheyed, S.H., and M. M. Elsahookie. 2011. Prediction percent of plants in the filed giving cultivar mean grain yield and up $(\bar{X}+)$ by vigorous seedlings emerged from sand (SE/96h).The Iraqi J. Agric .Sci. 42(5): 15 -23 6. Elsahookie, M.M. and K.M. Wuhaib. 1991. A coefficient to adjust plant yield moisture. The Iraqi J. Agric. Sci., 22(1) :96- 98

7. Elsahookie, M.M. and F. Uraha, A. Mahmood and A. Shehab. 1999. Indirect 
estimation of plant seed yield and oil content in sunflower. The Iraqi J. Agric. Sci., 30 (2):309 -318

8. Elsahookie, M.M. and S.K. Eltaweel. 2001. Selection, heritability, and genetic gain of sunflower seed weight by parent- offspring regression. The Iraqi J. Agric. Sci., 32(1):99 108

9. Elsahookie, M.M., and S.H. Cheyed. 2013. Tables to estimate maize leaf area by measuring one leaf length. The Iraqi J. Agric. Sci., 44 (2):164-167

10. Elsahookie, M.M. and S. H. Cheyed. 2014. Estimating sorghum leaf area by measuring one leaf length. The Iraqi J. Agric. Sci., 45(1): $1-5$

11. Elsahookie, M.M. and S. H. Cheyed and M.J. Al-Khafajy. 2014. Predicting maize ear grain weight in situ by ear dimensions. The Iraqi J. Agric. Sci., 45 (6): 531-536

12. Hardan, H.M. and M.M. Elsahookie. 2014. Leaf area estimation in sunflower and capitulum diameter - seed yield regression. The Iraqi J. Agric. Sci., 45(5):439-447

13. Kandil, A.A. and S.I. Elmohandes. 1988. Head diameter of sunflower an indicator for seed yield. Helia, 11:21 -23

14. Karcher, D.E. and M.D. Richardson. 2003.

Quantifying turf grass color using digital image analysis. Crop Sci., 43:943- 951

15. Nielson, R.L. 2013. Effects of stress during grain filling in corn. Corn News Network ,Purdue Univ. Online at: http://www.kingcorn.org/news/timeless/Grai nFilStress.html

16. Pirani, V. 1981.Analysis des correlations enter caracteres quantitatiessur grains de tournesol (H. annus L.). Eng. summary.

17.Scharf, P. C. and J. A Lory. 2002. Calibrating corn colorfromaerial photographs to predict sidedress nitrogen need. Agron. J., 94 :397-404

18. Singh, B., Y. Singh, J.K. Ladha, K.F. Bronson, V. Balasubramanian, J. Singh, and S. Khind. 2002. Chlorophyll meter and leaf color chart - based nitrogen management for rice and wheat in Northwestern India. Agron. J., 94:821-829

19. Turner. N.C. and H.M. Rawson. 1982. Yield and harvest index of sunflower cultivars: Influence of duration and water stress $.10^{\text {th }}$ Intl. Sunflower Conf., Surfers Paradise, Australia, p.6-8

20. Vranceanu, A.V., F.M, Stoenescu, and M. Terben. 1982. Tolerance of sunflower hybrids to competition among plants. Helia, 5:23-26. 